\title{
Synchronously diagnosed lymph nodal collision tumor of malignant melanoma and chonic lymphocytic leukemia/small lymphocytic
} lymphoma: case report

\author{
Dina El Demellawy¹, Catherine Ross², Monalisa Sur ${ }^{2}$ and Salem Alowami*2
}

\begin{abstract}
Address: ${ }^{1}$ Northern Ontario School of Medicine, Department Of Pathology and Laboratory Medicine, West Campus, Thunder Bay, Ontario, Canada and ${ }^{2}$ McMaster University, Department Of Pathology and Molecular Medicine, Hamilton, Ontario, Canada

Email: Dina El Demellawy - dina_eldemellawy@rogers.com; Catherine Ross - rossc@hhsc.ca; Monalisa Sur - surm@hhsc.ca; Salem Alowami* - alowami@hhsc.ca

* Corresponding author
\end{abstract}

Published: 30 August 2007

Diagnostic Pathology 2007, 2:34 doi:10.1 186/1746-1596-2-34

This article is available from: http://www.diagnosticpathology.org/content/2/I/34

(C) 2007 El Demellawy et al; licensee BioMed Central Ltd.

This is an Open Access article distributed under the terms of the Creative Commons Attribution License (http://creativecommons.org/licenses/by/2.0), which permits unrestricted use, distribution, and reproduction in any medium, provided the original work is properly cited.
Received: 24 May 2007

Accepted: 30 August 2007

\begin{abstract}
Synchronous composite tumors have been described but are uncommon. Moreover, simultaneous occurrence of synchronous tumors in the same tissue or organ is even less common. We report a case of chronic lymphocytic leukemia (CLL)/small lymphocytic lymphoma and malignant melanoma (MM) occurring synchronously in the same lymph node. Several cases of an association between cutaneous malignancies and lymphoproliferative disorders have been reported. Some of which included CLL and MM, occurring in the same patient often CLL after MM. The risk of having CLL after MM has been reported to be increased. Various genetic and environmental etiologies have been postulated, but have as yet not been proven. To our knowledge this is the first time that synchronous occurrence of these two malignant processes in the same tissue is described. In this case it is important that the melanoma was recognized in the excised lymph node, as this finding had much more critical treatment and long term survival consequences.
\end{abstract}

\section{Background}

Synchronously diagnosed concomitant tumors are uncommon, and occurrence of collision tumors is rare. We report a case of chronic lymphocytic leukemia (CLL)/ small lymphocytic lymphoma (SLL) and malignant melanoma (MM) occurring synchronously in the same lymph node. CLL and MM occurring in the same patient, often CLL after MM with a standardized incidence ratio of 2.3 [1]. Nevertheless, the relative risk of having CLL after MM has been reported to be increased (standardized incidence ratio of 2.3)[1] and the converse (i.e. melanoma) after CLL also occurs with and estimated observed to expected ratio of 2.79 [2].
Various genetic and environmental etiologies have been postulated, but have as yet not been identified. To our knowledge this is the first time that synchronously diagnosed collision tumor formed of CLL/SLL and MM is described. In this case it is important that the melanoma was recognized in the excised lymph node, as this finding had much more critical treatment and long term survival consequences.

\section{Case presentation}

A 58 year old man presented with a right axillary mass, of 4 months duration. He was otherwise relatively well and asymptomatic. Past medical history was significant for two previous excisions of cutaneous lesions, which were 
diagnosed as $\mathrm{MM}$ involving the left and right sides of the back, nine years and two years ago respectively. The patient has no history of receiving chemo or radiotherapy. A physical examination performed at this time revealed a right axillary mass with local tenderness measuring $10.0 \times$ $8.0 \mathrm{~cm}$. The patient had been experiencing night sweats, fevers and a twenty pound weight loss. The remainder of the physical examination was significant for splenomegaly, with the spleen tip palpated $7 \mathrm{~cm}$. from the left lower costal margin. No other lymphadenopathy or organomegaly was detected.

\section{Hematologic investigations}

The peripheral blood showed a white blood cell count of $20.2 \times 10^{9}$ (reference range: $5-11 \times 10^{9}$ ). In addition, the $\mathrm{CBC}$ revealed hemoglobin value of $12.6 \mathrm{~g} / \mathrm{dl}$ (reference range for men: $14.0-18.0 \mathrm{~g} / \mathrm{dl}$ ), and platelets was $203 \times$ $10^{-6} /$ Liter (reference range: 150,000 to 450,000 platelets per microliter) of blood. The peripheral smear showed smudge cells.

As the patient presented with lymphadenopathy and showed leukocytosis in the peripheral blood, flow cytometry was performed on the patient's peripheral blood. This showed a small population of monoclonal B cells with Kappa light chain restriction, indicating a lymphoproliferative disorder. The cells were CD5 and CD23 positive and CD38 and FMC7 negative. This phenotype is diagnostic of CLL in the presence of the morphological features in the peripheral blood smear.

Excision of the lymph node showed effacement of the normal nodal architecture by a lymphoproliferative disorder composed of small cells (fig. 1), which on immunohistochemistry [table 1] were CD20, CD5 (fig. 2), bcl-2 (fig. 3), CD23 (fig. 4) positive, CD10 and cyclin D1 negative compatible with small lymphocytic lymphoma. Only a single section showed a small metastatic focus of MM (fig. 5), measuring $1.5 \mathrm{~mm}$ in maximum diameter. This was of the epithelioid type that expressed MM markers, (fig. 6, 7) consistent with the previous diagnosis.

\section{Clinical outcome}

The patient had a re-excision of the growing axillary mass. He then had a new supraclavicular lymph node about one month later as well as persistent edema of the right arm. He received some radiation treatment at this time, after which he appeared stable for about four months. The patient then presented with shortness of breath and feeling unwell, and CT scan showed multiple nodules in the lung fields consistent with metastatic disease, at which time chemotherapy was started.

\section{Discussion}

Synchronously diagnosed collision tumors are considered a rare occurrence.

Cases presenting as multiple primary neoplasms may occur concurrently as collision tumors or may be separated temporally. It is important to realize that the constellation of neoplasms may be more than coincidental and may reflect underlying shared etiologic factors or may be related to altered immunity [3], particularly given the immunologic derangements that are known to occur with CLL. Of course, underlying genetic susceptibilities may also play important, although as yet not well delineated roles.

In the current case, we report a composite MM and CLL involving a single lymph node in a patient with MM diagnoses known previously. However, his past medical history indicates absence of chemo or radiotherapy; that may contribute to the present evolution of CLL. CLL and MM have been reported previously as a metachronously diagnosed tumors in the English literature with MM usually a subsequent cancer in patients with CLL [4]. CLL/SLL

Table I: The panel of immunohistochemical reagents used

\begin{tabular}{|c|c|c|c|}
\hline Antibody & Clone & Manufacturer & Dilution \\
\hline CD 20 & $\mathrm{~L} 26$ & Dako (Carpinteria, CA) & $1 / 1000$ \\
\hline $\mathrm{Bcl} 2$ & 124 & Dako (Carpinteria, CA) & $1 / 25$ \\
\hline CD 5 & $4 C 7$ & $\begin{array}{l}\text { Novocastra (Vision Biosystem, } \\
\text { Norwell, MA) }\end{array}$ & $1 / 50$ \\
\hline CD 23 & $|B| 2$ & $\begin{array}{l}\text { Novocastra (Vision Biosystem, } \\
\text { Norwell, MA) }\end{array}$ & $1 / 50$ \\
\hline CD 10 & $56 C 6$ & $\begin{array}{l}\text { Novocastra (Vision Biosystem, } \\
\text { Norwell, MA) }\end{array}$ & $\mathrm{I} / 25$ \\
\hline Cyclin DI & SP4 & $\begin{array}{l}\text { MEDICORP/LAB VISION } \\
\text { (Montreal, Quebec) }\end{array}$ & $\mathrm{I} / 75$ \\
\hline S 100 & SI00 & Dako (Carpinteria, CA) & $1 / 4000$ \\
\hline Pan melanoma cocktail & HMB45, MART-I, Tyrosinase & $\begin{array}{l}\text { BIOCARE MEDICAL (Concord, } \\
\text { CA) }\end{array}$ & $1 / 500$ \\
\hline HMB 45 & HMB 45 & Dako (Carpinteria, CA) & $\mathrm{I} / 200$ \\
\hline
\end{tabular}




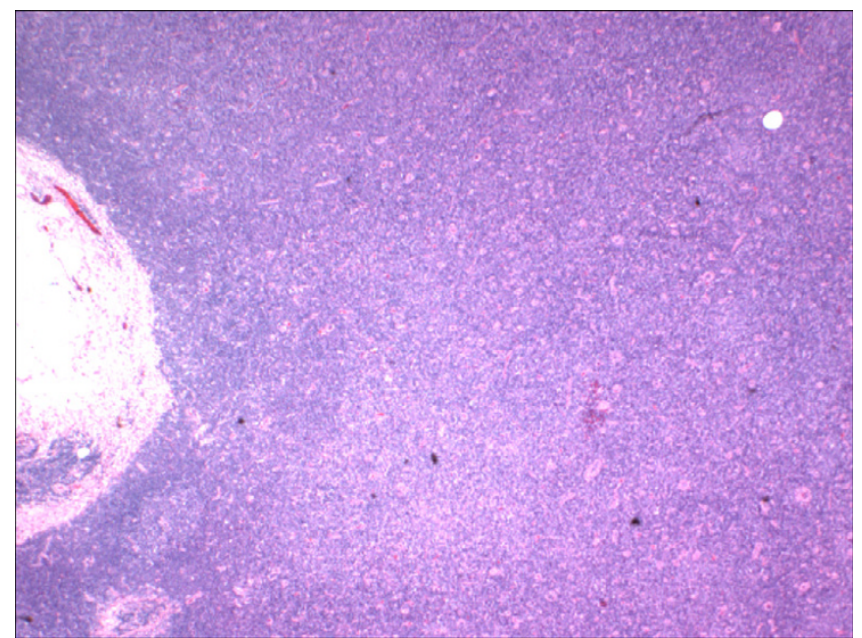

\section{Figure I}

Lymph node involved with chronic lymphocytic leukemia showing architectural effacement, (HE 40x).

developing after MM has also been reported. As far as we know only two synchronously diagnosed cases of CLL and MM have been reported previously in the English literature $[5,3]$ [table 2], but none of these cases showed collision involvement of MM and CLL within the same site/ organ.

Synchronously diagnosed collision tumors of non Hodgkin's lymphomas (NHL) and MM have been reported involving the same lymph node [5-7]. Such reports include follicular, mantle and diffuse large cell lymphomas [5-7]. The current report adds to the list CLL and MM

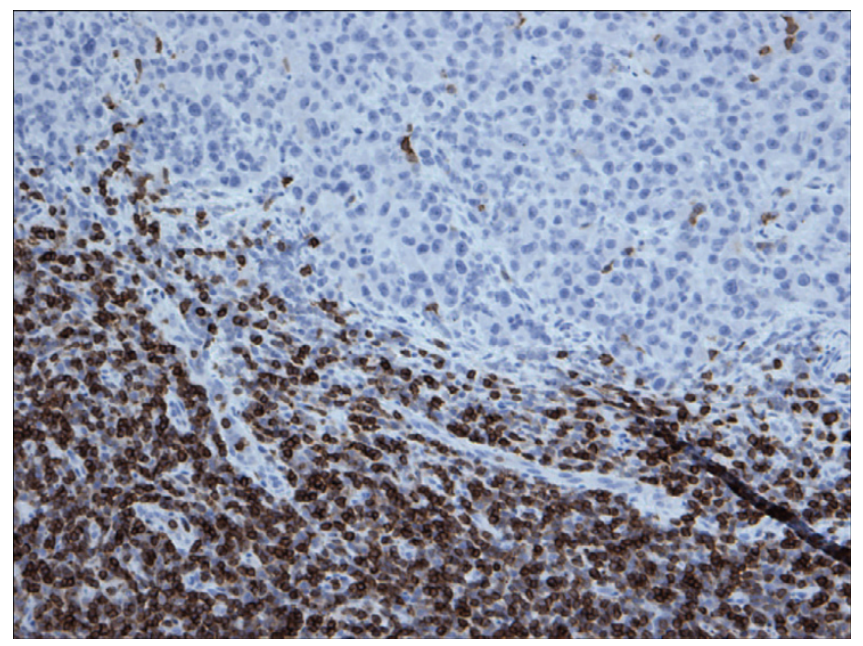

Figure 2

Restricted expression of CD5 within the lymphocytes in chronic lymphocytic leukemia in contrast to malignant melanoma cells, (CD5 200x).

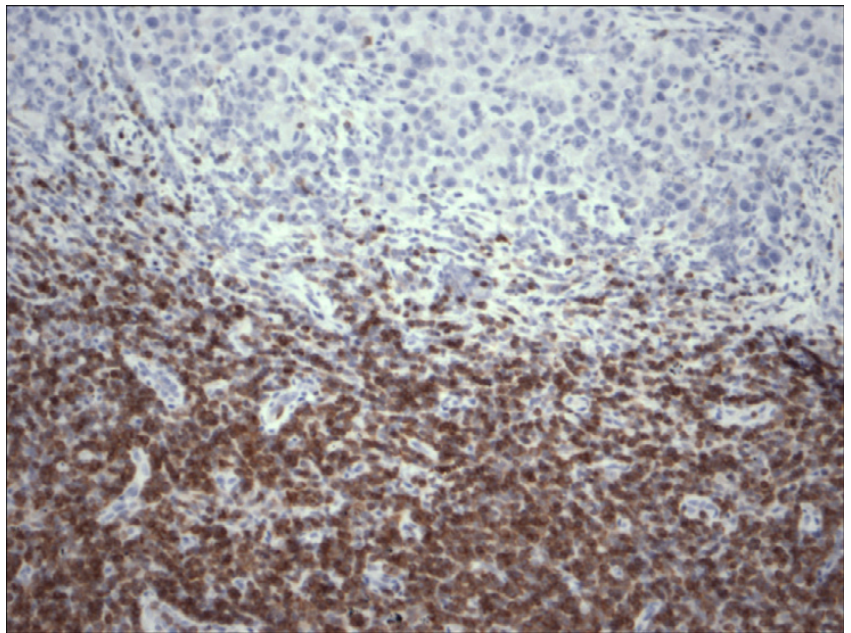

\section{Figure 3}

Restricted expression of $\mathrm{Bcl}-2$ within the lymphocytes in chronic lymphocytic leukemia in contrast to malignant melanoma cells, (Bcl-2 200x).

which is to the best of our knowledge is the first report of synchronously diagnosed CLL and MM involving the same node at the same time.

The association of malignant melanoma with other malignancies has been reported, including lymphoma, breast cancer, leukemia[8] and renal cell carcinoma [9]. In addition, there is a known risk of risk of second malignant neoplasms in CLL patients, including malignancies of the lung, the brain and MM [2].

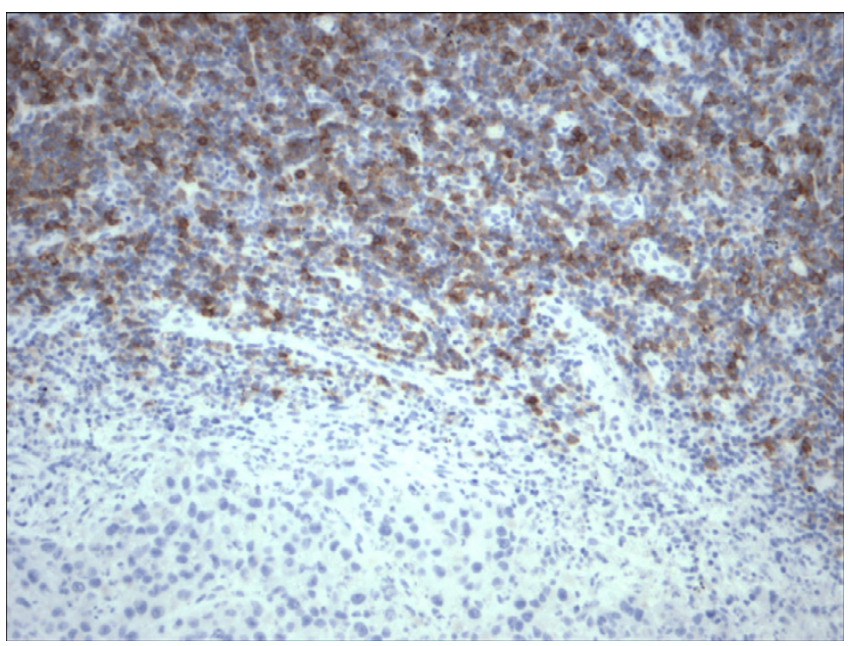

Figure 4

Restricted expression of CD23 within the lymphocytes in chronic lymphocytic leukemia in contrast to malignant melanoma cells, (CD23 200x). 


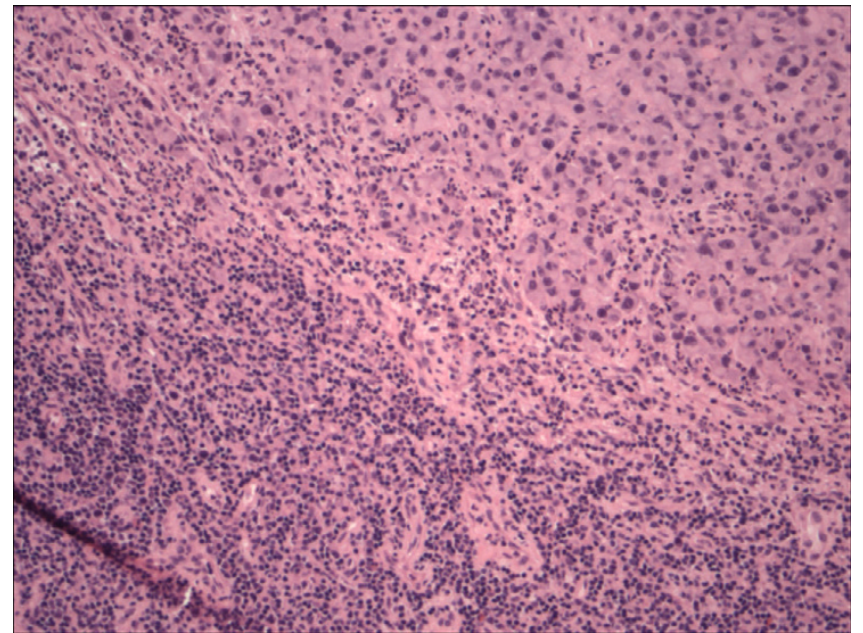

\section{Figure 5}

Simultaneous lymph node involvement by large epithelioid melanoma cells and small monotonous lymphocytes of chronic lymphocytic leukemia, (HE 200x).

Mature B cell neoplasms comprise $4 \%$ of new cancers each year around the world [10] and they account for over $90 \%$ of lymphoid neoplasms world wide [11]. About $6.7 \%$ of non Hodgkin lymphomas are classified as SLL/ CLL [11]. The majority of CLL patients are $>50$ years old with a median age of 65 years [12].

The median age at diagnosis of MM is 53 years as $\mathrm{MM}$ is now the commonest malignancy in Caucasians, between 25 and 29 years and in Caucasian men between 35-39 years [5]. The relative risk of subsequent $\mathrm{MM}$ for those

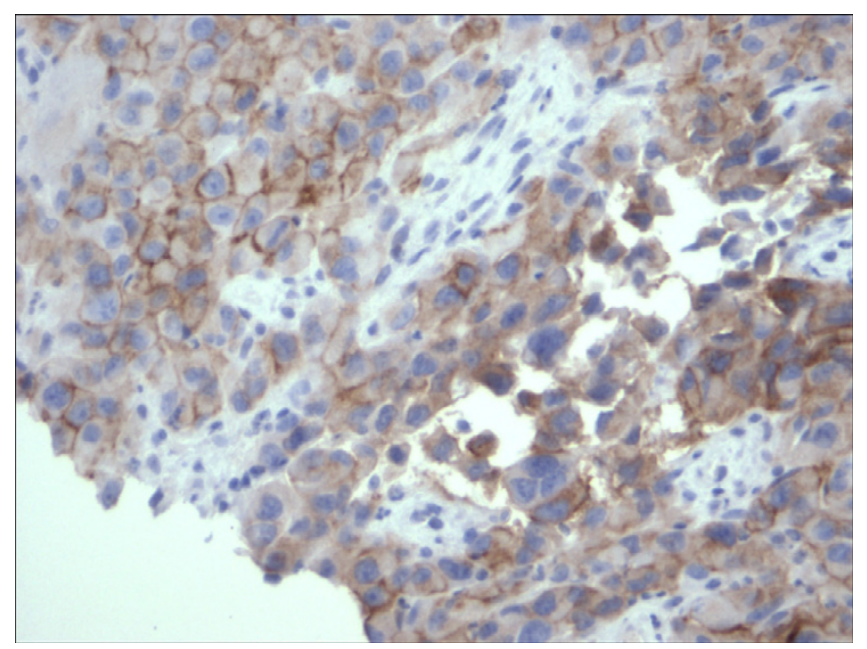

Figure 6

Expression of Melanoma cocktail within the cytoplasmic membranes of the malignant melanoma cells, (Melanoma cocktail 400x).

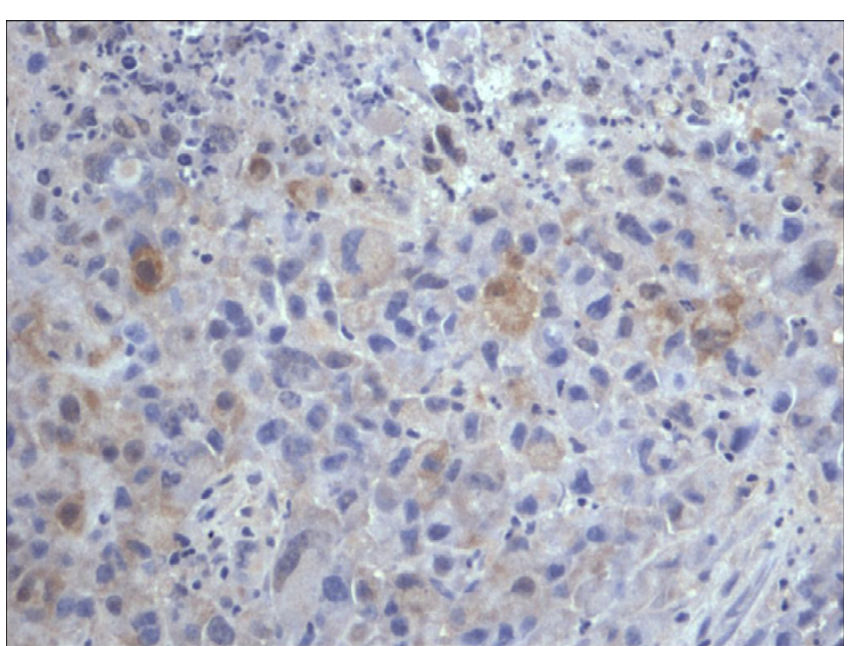

\section{Figure 7}

Expression of $\mathrm{SIOO}$ within the nuclei and cytoplasm of the malignant melanoma cells, (Melanoma cocktail 400x).

with CLL has been estimated to be between 2.79 and 3.1 $[13,14]$.

Patients who have $\mathrm{MM}$ have been ascribed a future risk of 1.9 for developing CLL [2].

There is no identifiable common cytogenetic abnormality or oncogene known between CLL and MM at this time. Risk factors for developing malignant melanoma are known to include ambient overexposure to sun light and perhaps chemical exposure in some studies. With respect to CLL, there are no proven studies to document sun light overexposure or chemical as risk factors. However, UVB present in sunlight has been suggested as a risk factor by inducing immunosuppressive effects through deficient antigen presentation and reduced $\mathrm{T}$ cell activity $[15,16]$.

Composite tumors do raise the question of possible etiological links and are of academic interest from this point of view. More immediate questions include the impact of composite tumors on management and prognosis. Though CLL is eventually lethal, it usually takes a protracted and indolent course. The overall median survival of CLL is 7 years [10]. On the other hand, MM stage II and above presents a rather more significant survival threat. Most then would consider that the primary target is to manage the MM. Cytotoxic therapy, which is the mainstay of systemic therapy for lymphoma[17], has a limited efficacy in $\mathrm{MM}$ [5]. Although both $\mathrm{MM}$ and lymphoma are radiosensitive[18] this raises issues of secondary undesired consequences as radiation to areas of previous lymphadenectomy show a higher risk of subsequent lymphedema ( 20\%)[5]. 
Table 2: Reported cases of chronic lymphocytic leukemia/small lymphocytic lymphoma (CLL) and malignant melanoma (MM).

\begin{tabular}{|c|c|c|c|c|c|c|c|c|}
\hline $\begin{array}{l}\text { Cases } \\
\text { reported }\end{array}$ & Age/Gender & Risk factor & Sites MM/CLL & $\begin{array}{l}\text { Breslow } \\
\text { thickness }\end{array}$ & Clark's level & $\begin{array}{l}\text { Stage MM/ } \\
\text { CLL }\end{array}$ & $\begin{array}{l}\text { Interval between the } \\
\text { diagnosis of the two } \\
\text { tumors }\end{array}$ & $\begin{array}{l}\text { Follow up/ } \\
\text { duration }\end{array}$ \\
\hline $\begin{array}{l}\text { Schmid- } \\
\text { Wendtner } \\
\text { MH et al, } \\
2002\end{array}$ & $46 / F$ & None & $\begin{array}{l}\text { Shoulder(MM } \\
\text { )/Axillary LN } \\
\text { (CLL) }\end{array}$ & $3 \mathrm{~mm}$ & IV & III/I & $\begin{array}{l}\text { Metachronous (MM } \\
\text { presented first) }\end{array}$ & Not reported \\
\hline $\begin{array}{l}\text { Cahill RA et } \\
\text { al, 200I }\end{array}$ & $67 / F$ & Present* & $\begin{array}{l}\operatorname{Lip}(M M) / B M \\
(C L L)\end{array}$ & $>3 \mathrm{~mm}$ & V & III/I & $\begin{array}{l}\text { Metachronous (CLL } \\
\text { presented first) }\end{array}$ & $\begin{array}{l}\text { Well/6 } \\
\text { months }\end{array}$ \\
\hline Current case & $68 / M$ & None & $\begin{array}{l}\text { Back(MM)/ } \\
\text { Axillary LN } \\
\text { (MM \& CLL) }\end{array}$ & $>3 \mathrm{~mm}$ & III & III/II & $\begin{array}{l}\text { Synchronous (MM \& } \\
\text { CLL on recurrence) }\end{array}$ & Well/2 years \\
\hline
\end{tabular}

* Farmer with history of exposure to ambient sunlight and carcinogenic chemicals.

- BM: Bone marrow, LN: Lymph node.

We present a collision tumor of CLL and MM, a report to our knowledge has not been reported in the English literature. Through this case we reviewed the cases of synchronous CLL and MM and expanded on the incidence, demography, etiological correlation and management as well as prognostic implications. In this case the importance of diagnosing the small amount of malignant melanoma in the enlarged lymph node primarily occupied by CLL/SLL was of critical importance in this patient for decision making and treatment purposes, in addition to having a significant adverse impact on overall survival.

\section{Acknowledgements}

We thank the Board of Research Ethics in McMaster University for approving the current manuscript for publication.

\section{References}

I. McKenna DB, Stockton D, Brewster DH, Doherty VR: Evidence for an association between cutaneous malignant melanoma and lymphoid malignancy: a population-based retrospective cohort study in Scotland. Br J Cancer 2003, I 3:88(I):74-78.

2. Riou JP, Ariyan S, Brandow KR, Fielding LP: The association between melanoma, lymphoma and other primary tumors. Arch Surg 1995, 130:106I-1065.

3. Schmid-Wendtner MH, Lebeau A, Sander CA, Volkenandt $M$, Emmerich B, Wendtner CM: Lymphadenopathy detected by ultrasound examination as first diagnostic hint of chronic lymphocytic leukemia in a patient with melanoma. JEADV 2002, I 6:491-493.

4. Greene MH, Hoover RN, Fraumeni JF Jr: Subsequent cancer in patients with chronic lymphocytic leukemia - a possible immunologic mechanism. J natl Cancer Inst I 978, 6 I (2):337-340.

5. Cahill R, McGreal G, Neary P, Redmond HP: Synchronous high risk melanoma and lymphoid neoplasia. Melanoma Res $200 \mathrm{I}$, I I ( I 5):5 I 7-522.

6. Dickinson $M$, Wotherspoon A, Cunningham D: Sub-clinical disssemination of follicular lymphoma in normal sized lymph nodes may not be detected by radiological staging: a case of disseminated follicular lymphoma. 2006, 47(3):553-556.

7. St Peter SD, Roarke MC, Conley CR, Pockaj BA: Sentinel lymph node biopsy demonstrating concomitant melanoma and mantle cell lymphoma. Surgery 2002, I 3 I:2 I 6-2 I8.

8. Tihan T, Filippa DA: Coexistence of renal cell carcinoma and malignant lymphoma. Cancer 1996, 77:2325-2331.

9. Travis LB, Curtis RE, Hnakey BF, Fraumeni JF Jr: Second cancers in patients with chronic lymphocytic leukemia. J Natl Cancer Inst |992, 84: | 422-| 427.
10. Harris NL: Mature B-cell neoplasms. In tumors of hematopoietic and lymphoid tissues, World Health Organisation, $200 \mathrm{I}$. Published by IARC Press, International Agency for Reasearch on Cancer:|2I.

II. Anon: A predictive model for aggressive non Hodgkin's lymphoma. The international non Hodgkin's lymphoma prognostic factors project. N Engl J Med 1993, 329:987-994.

12. Muller-Hermelink HK, Montserrat E, Catovsky D, Harris NL: WHO classification of tumors: tumors of hematotopoietic and lymphoid tissues IARC press, Lyon-France; 200I:I27-I 29.

13. Adami J, Frisch M, Yuen J, Glimelius B, Melbye M: Evidence of an association between non Hodgkin's lymphoma and skin cancer. BMJ 1995, 3 1 0(6993): | 49|-| 495.

14. Levi F, Randimbison L, Te VC, La Vecchia C: Non Hodgkin's lymphoma, chronic lymphocytic leukemias and other skin cancers. Br J Cancer I996, 74( I I): I 847-1850.

15. Streilein JW, Taylor JR, Vincek V, Kurimoto I, Shimizu T, Tie C, Golomb C: Immune surveillance and sun-light induced skin cancer. Immunol Today 1994, I 5(4): I74- I79.

16. Saijo S, Bucana CD, Ramirez KM, Cox PA, Kripke ML, Strickland FM: Deficient antigen presentation and $T s$ induction are separate effects of ultraviolet radiation. Cell Immunol 1995, I 64(20): 189-202.

17. Armitage JO: Chemotherapy for non Hodgkin's lymphoma. Curr Opin Oncol 1992, 4(5): 189-202.

18. Shulamn LN, Mauch PM: Current role of radiotherapy in Hodgkin's and non Hodgkin's lymphoma. Curr Opin Oncol 1995, 7(5):42 I-425. 